\title{
26
}

\section{Upgrading the Belhar Stormwater System to Combat Pollution of the Kuils River}

\section{Zaheer Ortell}

A review of the stormwater system in the residential suburb of Belhar, Cape Town (South Africa) concluded that an existing retention pond was oversized. In addition, discharged runoff was increasing the levels of pollutants and litter in the Kuils River.

Remedial options were considered, inter alia an evaluation of a wet pond and a dry pond as management tools. Important factors included both water quantity (flow rates and volumes) and water quality (especially particulates).

SWMM (USEPA Storm Water Management Model) was used to simulate the hydrology of the Belhar catchment, and the hydraulics of the stormwater network. The analysis included typical rainfall event-based modeling of ponds and their overflow structures, and a first-order water quality study.

The results of the analysis prompted the selection of a dry pond as a pollution- and flood-mitigating measure. These results also led to an existing pond being partially filled in to allow for housing and commercial use.

\subsection{Introduction}

The nature of stormwater runoff in the greater Cape Town area is changing, to the ensuing detriment of rivers, lagoons, and the receiving bays. Impacts are twofold:

Ortell, Z. 2004. "Upgrading the Belhar Stormwater System to Combat Pollution of the Kuils River." Journal of Water Management Modeling R220-26. doi: 10.14796/JWMM.R220-26.

(C) CHI 2004 www.chijournal.org ISSN: 2292-6062 (Formerly in Innovative Modeling of

Urban Water Systems. ISBN: 0-9683681-9-0) 
1. a greater percentage of land with an impervious surface has reduced rainfall infiltration into the soil, and consequently more runoff occurs to channels and lakes; and

2. pollutants, ranging from gross litter and debris to solubles and particulates, are degrading overall water quality.

While stormwater management plans have generally catered for the increased volumes of runoff due to urban developments, addressing the accompanying increases in pollutant loading have only recently been prioritized. In recognition of this, local government agencies have begun initiatives such as the Kuils River Metropolitan Open Space System (1999) and its predecessor, the Kuils River Environmental Management Plan (1994), to conserve the threatened watercourses.

Tests in the Kuils River have indicated that the water quality is not suitable for irrigation or recreation (Ninham Shand, 1999). High phosphorus and nitrate concentrations have been measured, and the river and its associated wetlands are being degraded. Table 26.1 lists the results from water quality tests conducted on the Kuils River at Stellenbosch Arterial Road, between 1989 and 1998.

Table 26.1 Selected results of water quality tests.

\begin{tabular}{lll}
\hline Parameter & Value (Season) & Acceptable Standard \\
\hline Chemical Oxygen Demand & $73 \mathrm{mg} / 1$ (winter) & $75 \mathrm{mg} / 1$ \\
NO2 and NO3 as N & $5.5 \mathrm{mg} / 1$ (winter) & $\begin{array}{l}\text { Eutrophic conditions } \\
\text { develop }>3 \mathrm{mg} / 1\end{array}$ \\
& $2 \mathrm{mg} / \mathrm{l}$ (winter) & $0.25 \mathrm{mg} / 1$ \\
Total Phosphorus & 4000 counts $/ 100 \mathrm{ml}$ & 1000 counts $/ \mathrm{mg} / 1$ \\
Faecal Coliforms & $\left(80^{\text {th }}\right.$ percentile, summer) & \\
\hline
\end{tabular}

The residential suburb of Belhar discharges stormwater into the upper reaches of the Kuils River. Although stormwater flows are by nature intermittent and the Kuils River also receives the final effluent from two wastewater treatment works, the contribution of runoff towards river base flows and water quality cannot be overlooked.

The local municipal authority, the City of Tygerberg, commissioned an investigation of the suburb's stormwater system in 2001. Analysis and design followed, with construction taking place from March to August 2002.

This chapter describes the Belhar stormwater system; outlines the analyses performed in considering the retrofit options; summarizes simulation techniques used; and concludes with recommendations that can enhance both this project and future projects of a similar ilk. 


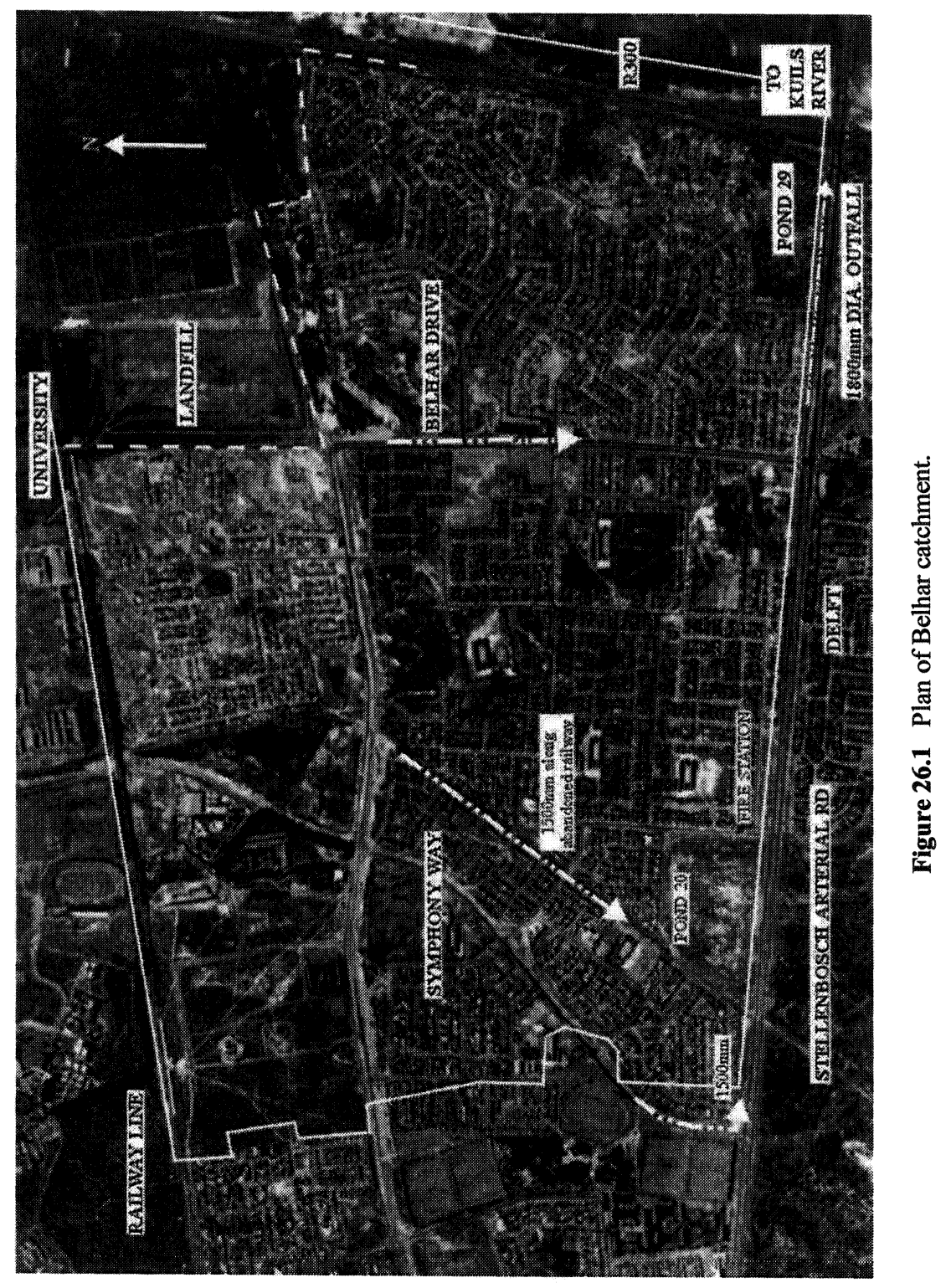


546 Upgrading the Belhar Stormwater System to Combat River Pollution

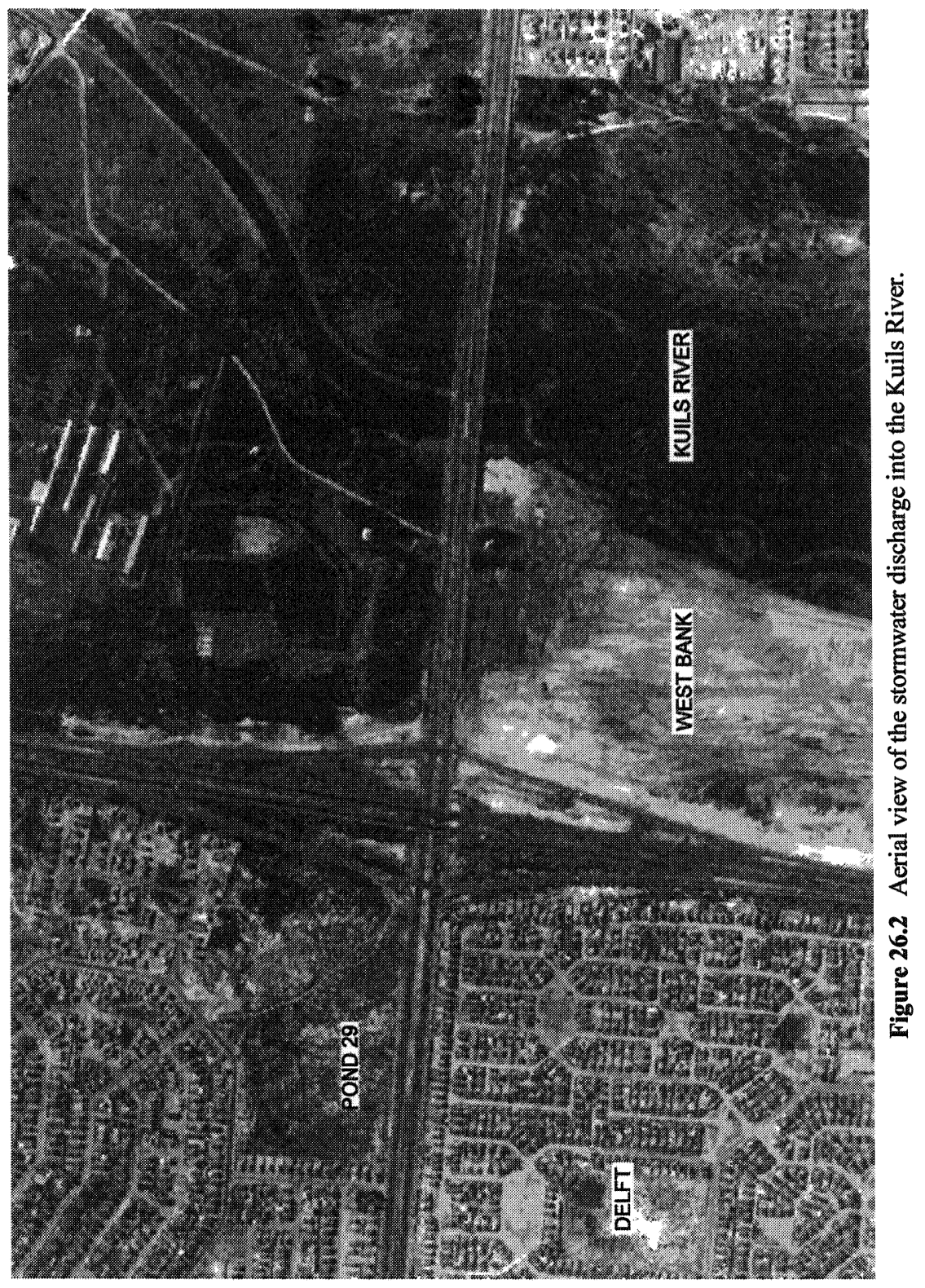




\subsection{Site and Catchment Description}

The residential suburb of Belhar is situated in the Cape Flats area to the east of central Cape Town, and immediately north of the airport. Originally farmland, most of the houses are new, as approximately 60,000 people were moved to the area since 1965. Surface soils in this $8 \mathrm{~km}^{2}$ catchment area are without exception calcareous sands, with the general water tables fluctuating from 0.5 $\mathrm{m}$ to $2.0 \mathrm{~m}$ below ground (winter) to 3.0 to $5.0 \mathrm{~m}$ below ground (summer).

Subdivisions are small $\left(200 \mathrm{~m}^{2}\right.$ is a median figure), and roads and sidewalks are asphalted or have concrete paving. Very little of the original flora has remained. In addition, many yards have been built-up, leading to a high overall percentage of impervious surface that is connected to the stormwaterhandling system.

The watersheds are man-made: the railway line and university campus to the north, Stellenbosch Arterial Road to the south, the R300 Freeway to the east, and the Erica Drive recreation grounds to the west. However, overland flow from the neighbouring Delft area can enter Stellenbosch Arterial Drive at several places (see Figures 26.1 and 26.2).

There is considerable pressure to develop existing open spaces in Belhar and its neighbouring townships of Delft and Westbank. Delft in particular is a growing site for low-income single-family residential dwellings. The construction activity adds to the silt and polluted runoff entering the Kuils River.

\subsection{The Existing Stormwater System}

Belhar has a kerb-and-gutter system alongside its roads, with collectors draining to three north-south pipes (of diameters up to $1.5 \mathrm{~m}$ ) along Symphony Way, the abandoned railway line, and Belhar Drive, respectively. These pipes in turn drain to a $1.8 \mathrm{~m}$ diameter concrete pipe within the Stellenbosch Arterial Road reserve, which crosses the R300 freeway and is routed directly onto the bank of the Kuils River. The outfall is elevated some 1.0 to $1.5 \mathrm{~m}$ above the dryweather level of the river.

An existing stormwater pond (Pond 20) is located at the head of the Stellenbosch Arterial pipeline. This pond is some $250 \mathrm{~m} \mathrm{x} 300 \mathrm{~m}$ in extent, sits offline, and drains completely between rainfall events as its floor level varies between one and two metres above the soffit level of the stormwater pipe. Stormwater can enter this pond only by surcharging two grated manholes. The 
pond floor was not cleared of bushes and shrubs, and only partially graded. The depth from bank to floor ranges from $1 \mathrm{~m}$ to $3 \mathrm{~m}$.

Downstream portions of the Belhar stormwater network are $5 \mathrm{~m}$ beneath the ground level, mainly due to the flat overall topography.

\subsection{Objectives of Retrofit Procedure}

The City of Tygerberg's goals (or terms of reference) in initiating this project were summarized in a previous report (Liebenberg \& Stander, 1991):

1. rationalize the land at its disposal (for both stormwater- and societal purposes);

2. reduce the runoff volumes entering the Kuils River;

3. reduce the total settleable solids (TSS) loading of the runoff;

4. reduce other pollutants, such as organic matter, litter, and nutrients; and

5. make the maintenance functions of the system as clear as possible, and to comply with the requirements of the municipal crews. As examples, equipment used to jet-clean foul sewers and manholes were available, but no manually operated valves or gates were considered.

Several other concerns were raised. The client was hesitant about the introduction of a wet pool because of the possibility of drowning, and also of indiscriminate dumping of rubble. Further, it was acknowledged that the problem of floatable litter amongst the stormwater could not be eliminated through a structural device alone.

\subsection{Design and Analysis Procedures}

SWMM was selected for the hydraulic/hydrologic simulations in the design procedure, specifically the 'Runoff' and 'Extran' blocks compiled by PC SWMM $2000^{\mathrm{TM}}$ (distributed by Computational Hydraulics International). The catchment data from an existing Witwat ${ }^{\mathrm{TM}}$ (Green, 1984) simulation model set up in 1991 was used as a starting point, and information such as the current land use was updated where required (the Witwat model had exclusively used design storms that were derived from $80 \mathrm{y}$ of rainfall observation at the airport). 
The procedure adopted was as follows:

1. the existing stormwater-handling system was analysed using SWMM;

2. a status report was submitted, which amended the hydraulic- and 'storage volume requirement' findings from the earlier design reports (a feasibility study to introduce a water quality treatment feature was included);

3. three remedial alternatives were tabled to address the pollutant load problem, and simulated in more detail (with respect to water quality); and

4. a 'preferred option' was taken through the detailed design phase, and built.

\subsubsection{The Existing Stormwater-handling System}

A short-term continuous simulation model was prepared in 2002 for the period 1989 to 1991, for which there was some anecdotal data regarding flows and depths in the pipes and ponds respectively. Discussions with residents who lived in the vicinity of Pond 20, and with officials of the nearby Fire Station (and consultation with their records), gave the modeling team a rough indication of the frequency with which excess runoff surcharged into Pond 20. This information was used for a rough calibration, i.e. catchment parameters were adjusted based upon the neighbours' observations and comments as to the surcharging frequency.

The results from the SWMM simulations were significantly different to those produced using the previous model, and were especially notable in two areas:

1. Pond 20 had considerable storage volume in excess of that required to detain the volumes generated using the 1 -in-50-y, $24 \mathrm{~h}$ storm

2. The downstream portions of the minor system (the $1800 \mathrm{~mm}$ diameter concrete pipe) could pass flows attributable to shortduration storms with recurrence intervals of 1-in-20-y.

Some differences to results contained in prior design reports had been expected, as the Witwat simulation model does not cater for pressure-flow conditions in pipes (Green, 1984), or detailed manhole/chamber hydraulics.

A decision was made to prepare $40 \%$ of Pond 20 's surface area to provide land for future housing developments. 


\subsubsection{Types of Water Quality Improvement Practices Considered}

The City of Tygerberg had acquired a plot of undeveloped land sized $130 \mathrm{~m} \mathrm{x}$ $80 \mathrm{~m}$ (of area approx $1.2 \mathrm{ha}$, located adjacent to a property zoned for a school) for the purposes of a stormwater pond. The property is very near the pipe outfall into the Kuils River. The remedial alternatives considered due to the property's size and location were

1. An offline detention pond (with a permanent water pool, approximately $500 \mathrm{~mm}$ deep, which would release water back into the stormwater system after temporary storage)

2. An offline retention pond (similar to 1 , but which would completely drain between rainfall events, and which would aim more to control flow rate than flow quality), and

3. An offline infiltration basin (where there is no direct discharge of water back into the Kuils River)

These three options vary with respect to maintenance requirements, the land or volume necessary, and also the effectiveness with which the runoff is treated.

\subsubsection{System Hydraulics affected by the Proposed Pond Inlet Chamber}

A challenge was the need to get water into the pond from the existing $1800 \mathrm{~mm}$ diameter stormwater pipe, which has an invert some $4.5 \mathrm{~m}$ below the natural ground level. A large underground chamber built around the pipe, with a 2.5 $\mathrm{m}$ high diversion weir, was proposed, taking advantage of the excess storageand flow capacities in the pipe system.

The impact of the diversion weir was simulated using a SWMM model derived from the 'calibrated' model of the existing system. Simulated water levels in Pond 20 are presented in Figure 26.3, for two scenarios:

1. the existing (2001) Pond 20 and pipe system, and

2. the proposed system, i.e. with Pond 20 filled-in, and including the inlet chamber and diversion weir for the new downstream pond.

The results of the simulations indicated that the proposed changes would not introduce severe flooding problems upstream. Approximately $35 \%$ of the total runoff for the 3-y simulation was diverted into the new pond by the diversion weir.

However, the property size and volumes of water discharged precluded using an infiltration basin as a meaningful water quality improvement system. 


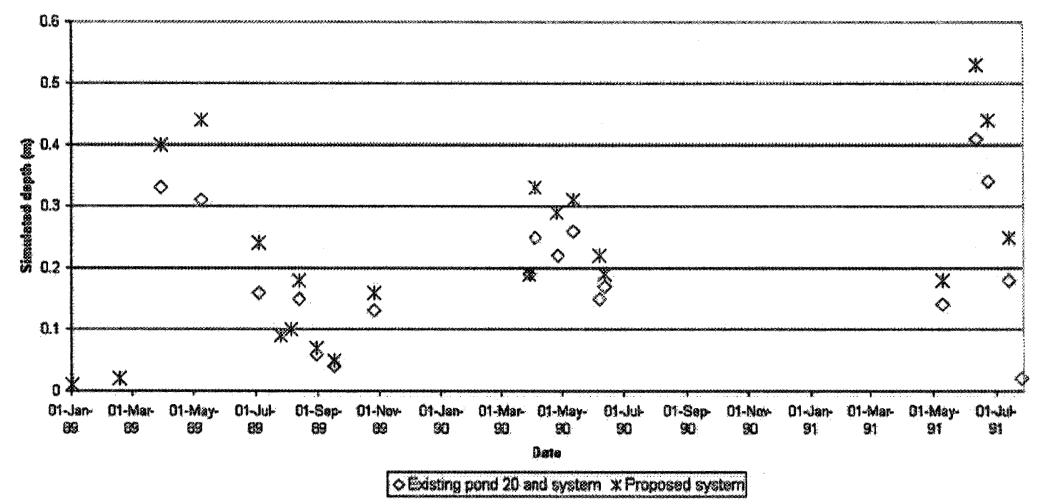

Figure 26.3 Results of simulations comparing the existing and proposed systems: Water levels in Pond 20.

\subsubsection{Storage Volumes within the New Pond (Pond 29)}

The water levels and functioning of all types of stormwater ponds are controlled by their outlet structures. The design team proposed two structures, i.e. one for each pond option, which would be simulated within SWMM. In essence, the level of the outlet device and the size of the outflow orifice were varied.

A series of design storms were introduced at the end of the short-term simulation's rainfall, to simulate the catchment with a true soil moisture starting point. Table 26.2 summarizes the design storm information.

The footprint and maximum recommended pond depth of $3.3 \mathrm{~m}$ afforded a storage volume of approximately $18,000 \mathrm{~m}^{3}$.

Table 26.2 Design storms used in pond hydraulics simulations.

\begin{tabular}{lcc}
\hline \multirow{2}{*}{ Return Period } & \multicolumn{2}{c}{ Total Rainfall during event } \\
\cline { 2 - 3 } & 2 hour duration & 24 hour duration \\
\hline Years & $\mathrm{mm}$ & $\mathrm{mm}$ \\
\hline 2 & 21 & 42 \\
5 & 28 & 55 \\
25 & 45 & 90 \\
50 & 55 & 111 \\
100 & 68 & 137 \\
\hline
\end{tabular}




\subsection{Introduction to Water Quality Modeling}

Some measure of the relative water quality improvement capabilities offered by the two options was therefore required in order to make a suitable choice. While it is standard practice in stormwater management to calculate pond volumes using hydrologic/hydraulic models, a quantitative assessment of water quality is performed much less frequently. In addition, any calibration of parameters is impossible without a set of measurements taken during storm events.

\subsubsection{Analysis of Stormwater Quality Improvements with Ponds}

Wetlands within stormwater ponds use several mechanisms to remove pollutants (Hunt et al 2000); these include sedimentation and filtration of solids, and adsorption of soluble metals. Microbial activity to remove organic nitrogen from stormwater is also promoted.

Sedimentation occurs as water is slowed down entering the pond, loses kinetic energy, and is less able to sweep along items such as fine sands and litter. Suspended particles then settle to the bottom of the water column, and might be deposited on the pond floor. The greater the reduction in water velocity that can be achieved increases the amount of sedimentation that may take place.

Filtration is the straining of stormwater by the leaves and stems of plants in the pond. A critical factor here is the length of reedbeds in the direction of flow through which the stormwater passes.

Adsorption is the attraction of soluble phosphorus and dissolved metals (as ions) to soil particles on the floor of the stormwater pond. Greater soil-water contact area and -time increase adsorption, but frequent scarification of the pond bottom is required in order to maintain a fresh layer of soil uppermost.

Table 26.3 Wetland removal mechanisms and pollutants.

\begin{tabular}{ll}
\hline Pollutant removal mechanism & Pollutants \\
\hline Sedimentation and filtration & $\begin{array}{l}\text { Total suspended solids, floating debris, litter, } \\
\text { some phosphorus and pathogens }\end{array}$ \\
$\begin{array}{l}\text { Adsorption to soil particles } \\
\text { Microbial processes, including } \\
\text { nitrification and denitrification } \\
\text { Plant uptake (and reed harvesting) }\end{array}$ & $\begin{array}{l}\text { Nitrogen, organics, and pathogens } \\
\text { Small amounts of nutrients, including phosphorus } \\
\text { and nitrogen }\end{array}$ \\
\hline Exposure to sunlight, and dryness & Pathogens \\
\hline
\end{tabular}

(Adapted from Brix, 1993). 
Wetlands are also a platform for the growth of aerobic and anaerobic bacteria responsible for converting organic nitrogen first to ammonia, and then to nitrogen gas, before dispersion to the atmosphere.

\subsubsection{Selection of the Water Quality Simulation Model}

The complex biological and chemical processes that occur within stormwater ponds and wetlands are apparent. The variety and level of information that must be incorporated into a detailed water quality and wetland analysis is typified by simulation software such as PDMOD (Lawrence, 1999, and 2001) which includes factors such as ambient temperature, wind speeds, rainfall, pond shape, soil strata, sunlight and influent water quality parameters.

Accepting that simulation error was inevitable, and that the information available would not allow such a rigorous exercise, a series of basic calculations comparing the available treatment options was performed instead. The initial choice of software for the water quality analysis was SWMM, because of the existing hydrologic model that could be used directly as an input sequence.

The Storage-Treatment (S-T) block within SWMM enables a first-order assessment to be made of the pollutant removal within a treatment unit. While originally envisaged to replicate the functioning of a wastewater treatment plant, the S-T block has been applied to simulate stormwater ponds.

However, the S-T block has been used as a basis for a simplified assessment (Newman et al, 1998). A spreadsheet was developed to use the SWMM pollutant-removal rates while avoiding the duplication of multiple input files and large results files. A similar approach was adopted for the Belhar catchment.

\subsubsection{Application of the Spreadsheet to Simulate TSS Removal within Pond 29}

The spreadsheet method was used to simulate the removal of settleable solids only, as no attempt was made to represent the complex nitrogen- or phosphoruscycles.

The S-T block calculates general pollutant removal according to the equation below (Huber et al, 1988):

$$
E=E_{\max } \cdot\left(1-e^{-k . t}\right)
$$

where: 


$$
\begin{aligned}
E & =\text { overall pollutant-removal efficiency (the result of the } \\
& \text { calculation) } \\
E_{\max }= & \text { maximum removal fraction expected for the pond, } \\
k & =\text { decay rate of the pollutant per time step, } \\
t= & \text { time elapsed (time step), and } \\
e & =\text { base of the natural logarithm, i.e. } 2,718 .
\end{aligned}
$$

It was acknowledged that while SWMM performs a removal calculation for each time step (and hence for each discrete volume of water entering and leaving the pond), the spreadsheet adopts a uniform treatment value for the entire body of water in the pond. In this way, the spreadsheet is unable to produce a time-series of any pollutant value throughout a storm, and the simulation results can be likened to a mean concentration for the storm.

Neither method takes into account the direct loss of stormwater via infiltration through the pond floor and sidewalls. This is significant for unlined ponds on the Cape Flats as the underlying soils are sandy.

The necessary input variables to obtain results for Equation 26.1 are $\mathrm{E}_{\max }$, $\mathrm{k}$, and $\mathrm{t}$. The initial values of these variables are shown in Table 26.4. TSS removal efficiencies of $70 \%$ and $60 \%$ were taken from a literature survey (Sear et al., 1999; Rushton et al., 1999).

Table 26.4 Input data for TSS-removal spreadsheet.

\begin{tabular}{lccc}
\hline & $\mathrm{E}_{\max }$ & Eretention time of 1 day & $\mathrm{t}$ (days) \\
\hline Detention pond "wet" & 0.70 & 0.60 & Set as 1.0 \\
Retention pond "dry" & 0.65 & 0.50 & 1.0 \\
\hline
\end{tabular}

For dry ponds, $\mathrm{k}$ was calculated as 1.466 (by substituting the values in Table 26.3 into Equation 26.1, and by making $k$ the subject of the formula). Conversely, $\mathrm{k}$ was calculated as 1.946 for wet ponds, which reflected the general observation that wet ponds are more effective at achieving settling over a specified time period than dry ponds.

The spreadsheet was applied to the real storms to calculate the pond effectiveness. The layout of the spreadsheet (adapted from Newman et al, 1998) with typical results is presented in Table 26.5.

The spreadsheet demonstrated - for this representation of pollutantremoval - that increasing the residence time was key in achieving meaningful improvements in water quality. However, sufficient stormwater must be released to prevent spilling over the pond banks. This step requires careful 
Table 26.5 Spreadsheet-calculated performance of a dry pollution-control pond (for selected storms of 1989).

\begin{tabular}{|c|c|c|c|c|c|c|c|}
\hline 1 & 2 & 3 & 4 & 5 & 6 & 7 & 8 \\
\hline Date & $\begin{array}{l}\text { Rain } \\
\text { fall }\end{array}$ & $\begin{array}{l}\text { Vol. of } \\
\text { stormwater } \\
\text { entering } \\
\text { pond }\end{array}$ & $\begin{array}{l}\text { Max } \\
\text { depth } \\
\text { of } \\
\text { water } \\
\text { in pond }\end{array}$ & $\begin{array}{l}\text { Peak } \\
\text { out- } \\
\text { flow } \\
\text { rate }\end{array}$ & $\begin{array}{l}\text { Mean } \\
\text { outflow } \\
\text { rate }\end{array}$ & $\begin{array}{l}\text { Mean } \\
\text { resid- } \\
\text { ence } \\
\text { time }\end{array}$ & $\begin{array}{l}\text { Removal } \\
\text { efficiency }\end{array}$ \\
\hline & $\mathrm{mm}$ & $\mathrm{m}^{3}$ & $\mathrm{~m}$ & $1 / \mathrm{s}$ & $1 / \mathrm{s}$ & $\mathrm{h}$ & \\
\hline 19-21Apr & 62 & 91000 & 2.30 & 355 & 115 & 9 & $27 \%$ \\
\hline 31May & $\begin{array}{l}51(6 \\
h)\end{array}$ & 71500 & 2.45 & 359 & 119 & 5 & $17 \%$ \\
\hline $24,25 \mathrm{Jul}$ & 36 & 60500 & 2.00 & 334 & 110 & 13.5 & $38 \%$ \\
\hline 17Sep & 16 & 18600 & 1.25 & 256 & 95 & 11 & $32 \%$ \\
\hline
\end{tabular}

Note: Values from columns (3), (4), (5), (6) and (7) came from SWMM-EXTRAN

output. Column (8) was computed using the spreadsheet method (Newman et al, 1998).

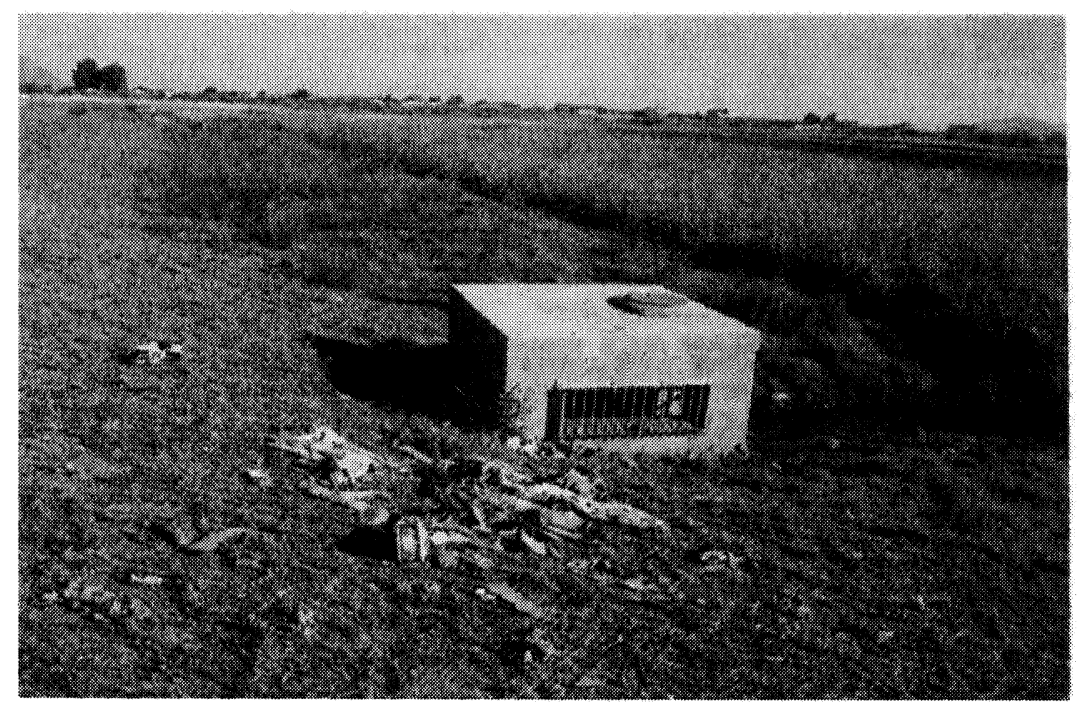

Figure 26.4 Outlet structure: side inlet for high flow conditions.

selection of the outlet control device: side-inlets were therefore included in the design to augment the orifice located at the bottom of the outlet structure. The side-inlets would be active when the pond depth at the outlet is approximately $1.0 \mathrm{~m}$ (see Figure 26.4). 
The simulations indicated that a wet pond would provide between $6 \%$ to $8 \%$ greater opportunity for settling to occur. A strategic decision was made that this benefit would not justify the additional maintenance tasks required over and above those of a dry pond.

In practice, litter collects at several points in the pond, and at the base of the diversion weir. Consequently, the litter load entering the Kuils River from Belhar has decreased by almost $55 \%$.

\subsection{Discussion}

The investigation into the Belhar stormwater-handling system revealed that excess capacity existed in an upstream retention pond, and in the downstream discharge pipes. This afforded an opportunity to introduce a set of controls that aim to improve the overall stormwater discharge quality. An added benefit was the reclaiming of land in Pond 20 for other uses.

The level of analysis performed in order to make design decisions varied from very detailed in the case of water levels and flows, to the more general, as with the water quality assessment.

The long-term simulation yielded results about the overall relevance of the water quality pond, as a calculated $35 \%$ of the total runoff was diverted into the pond.

A discussion point that arose through the project was the positioning of dry pond inlets relative to the pipe system, with Pond 20 as an example. Results from the simulation models highlighted the sensitivity and importance of this item. It is critical that the hydraulic functioning of stormwater ponds be documented in order to test the design, and to find out whether there is scope for improvement.

The Tygerberg authority (within the City of Cape Town Municipality) have expressed interest in undertaking a regime of water quality testing, to test the efficiency of the dry pond.

A non-hydraulic lesson learnt, which is specifically applicable to lowincome communities, is to cater for some degree of salvaging of material. An alternative material to metal for pipe grilles or orifice-plates is suggested, as several grilles were damaged and some even removed immediately the Contractor left site. 


\subsection{Recommendations}

The following recommendations resulted from this case study:

1. Match the level of system analysis performed with the information available for a calibration step (i.e. using a simplified water quality assessment to assist decision-making, as little verifying data was available).

2. Establish a water quality test series to evaluate the pond's functioning, and to identify whether changes or improvements are required.

3. Interview local residents to augment information about open stormwater systems, especially where metered or gauged data is unavailable.

\section{References}

Brix, H, 1993. Wastewater Treatment in constructed wetlands: system design, removal processes and treatment performance, Wetlands for Water Quality Improvement, pp9-22, GA Moshiri (ed.), Boca Raton, FL., CRC Press

Green, I.R.A, February 1984, Witwat Stormwater Drainage Program - Theory, Applications and User's Manual, Water Systems Research Programme, University of the Witwatersrand, Report No $1 / 1984$

Huber, W.J., Dickinson, R.E., Roesner, L.A., and Aldrich, J.A., 1988, Storm Water Management Model, Version 4: User's Manual, University of Florida, and the Environmental Research Laboratory, United States Environmental Protection Agency

Hunt, W.F. and Doll, B, 2000, Urban Waterways: Designing Stormwater Wetlands for Small Watersheds, Technical Note, North Carolina Co-operative Extension Service, University of North Carolina

Keifer, C.J. and Chu, H.H., August 1957, Synthetic Storm Patterns for Drainage Design, Journal of the Hydraulic Division, ASCE

Lawrence, I, February 1999, Stormwater Pollution Control Pond \& Wetland Models, Proceedings of the 8th International Conference on Urban Drainage, Sydney

Lawrence, I, May 2001, Pond and Wetland Models, Description and Quality Assurance Report, Co-operative Research Centre for Freshwater Ecology, University of Canberra Press, Australia

Liebenberg \& Stander Consulting Engineers, June 1991, Belhar Stormwater Management Plan, Report commissioned by MrP van Wieringen, City Engineer, Tygerberg.

Newman, T., T.A. Omer and E.D. Driscoll. 1999. "SWMM Storage-Treatment for Analysis/Design of Extended-Detention Ponds." Journal of Water Management Modeling R206-17. doi: 10.14796/JWMM.R206-17. 
Ninham Shand Consulting Engineers, 1999, Kuils River Metropolitan Open Space System, Volume 1, in co-operation with Chittenden Nicks, Report to the Cape Metropolitan Council

Rushton, B, Miller, C, and Hull, C, September 1999, Residence Time as a Pollutant Removal Mechanism in Stormwater Detention Ponds, Proceedings of the Sixth Biennial Stormwater Research and Watershed Management Conference, Tampa, Fl., G England (ed.).

Sear, T.R. and Rayborn, H.M., September 1999, Wet Detention Facility Pollutant Removal Modelling, Proceedings of the Sixth Biennial Stormwater Research and Watershed Management Conference, Tampa, Fl., G England (ed.). 